\title{
U-Shaped Relationship Between Board of Directors’ Disparity And Corporates’ Strategy Adjustment
}

\author{
Liang $\mathbf{Q u}^{1, \text { a }}$, Linyan Zeng ${ }^{2, \mathrm{~b}, *}$ \\ ${ }^{1}$ MBA school, Zhejiang Gongshang University, Jiaogong Street, Hangzhou, China \\ ${ }^{2}$ School of Business Administration, Zhejiang Gongshang University, Xuezheng Street, Hangzhou, China

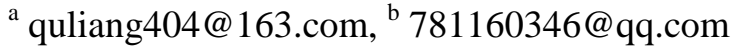

Keywords: Board diversity, Strategy adjustment, U-shaped, Executive chain network, Ownership structure

\begin{abstract}
We selected all A-share listed companies as a sample. Through the empirical analysis of three consecutive years' panel data from 2010 to 2013, we validated the U-type relationship between board of directors' disparity and strategic adjustment of the enterprise, and the moderating role of executive chain network. We found: (1) The impact of disparity on business diversification is U-shaped; (2) The adjustment effect of board network to the relationship between board disparity and corporates' strategy adjustment is rejected. This paper provides suggestions for the equity adjustment of boards' ownership structure, and presents evidence that external networks influences enterprises' strategic decision, thus providing a new theoretical perspective for China to generate a more mature specification for the board of directors 'system.
\end{abstract}

\section{Introduction}

Based on enterprises' interests, diversification of board of director has, either by design or as a result of natural changes, gradually become a daily phenomenon in organizations (Zhu and Shen, 2015). However, different from what some researchers expected, diversity is not always conducive to organizational performance, even the result along with a single dimension of diversity acting on the same variable is controversial (Homan et al, 2007). On one hand, when people make decisions, their own characteristics also make a difference. Diversity can bring more abundant and comprehensive perspectives for the team. Members with differentiated views, start a heated debate about the task, stimulate creative thinking and solve the problem. However, conflicts that come along with diversity, also make team coordination more difficult (Sutcliffe, 1994).

Current researchers who focus on diversification strategy mainly choose enterprise scale or the level of past performance as their penetration points. How does board of directors' internal equity distribution affect diversification strategy's adjustment, especially from the perspective of resource-based view, is the black box remained to be analyzed. Corporate executives are embedded in social network, therefore, the enterprises' strategic adjustment is affected not only by the degree of decision-making table's diversity, but also by the executives' network location. In our country, "relationship" in the process of enterprise development, is often taken as a replacement of formal system, and sometimes even becomes the key factor for enterprise success. When companies are connected to each other, resource sharing may come true. For example, by using questionnaire survey, Lin and Zhao (2013) found that human resource practices of setting up executive chain network have a positive influence on enterprise performance, but on the other hand, they also breed those self-interest oriented poor behavior. This paper, starting from the board of directors' disparity, putting A-share listed companies as samples, empirically tests the relationship between boardroom equity allocation and enterprise strategic adjustment, and the moderation effect of executives' chain network to this relationship. 


\section{Theoretical Analysis and Research Hypotheses}

\subsection{How do board of directors' disparity act on strategic adjustment: literature review}

\subsubsection{Classification of Diversity}

There are two logical lines of thinking in the classification of team diversity. One is that individual characteristics form team diversity, such as gender diversity, age diversity, etc. The other is the classification of diversity's expressive morphology. Harrison et al. (1998) proposed surface diversity and deep-level diversity. Surface diversity was the team members' differences that can be easily observed, while deep-level diversity refers to the differences in characteristics, such as attitudes, beliefs and values that require certain learning time. Other scholars classified board diversity according to its work relevancy (Stanciu, 2015). In principle, board diversity should include cognition diversity and mood diversity, but in an actual research process, board diversity is often used in relatively stable member attributes, such as some demographic stable characters including education, and job functions. DijK et al. (2012) found that the majority of diversity studies focused on gender, cultural background (including race or ethnicity), age, functional background and other dimensions. Studies have questioned the traditional view that task diversity has a positive influence on team performance, but the demographic dimension has a negative effect. They think it may be the result of the graders' bias, when more objective performance evaluation index is adopted, this conclusion will never occur. Recently, researchers have renewed interest in deep-seated diversity and began to focus on personality diversity, attitudes and other deep traits.

The term diversity is loosely used (or synonyms like heterogeneity and decentralization), but the exact meaning of diversity is not clear. The results of most studies of diversity are mixed and there is no obvious pattern (Jackson et al, 2003). The construction and refinement of diversity deserve further consideration.

\subsubsection{Internal Equity of Board's Checks and Balances}

Based on agency theory, Shleifer and Vishny (1997) argue that equity concentration can provide effective supervision mechanism, and can solve equity dispersion caused by agency conflict between shareholders and managers. The research of Gorton and Schmid (1999) also shows that major shareholders can solve the problem of collective action of shareholders in decentralized shareholding structure. Kim et al. (2011) pointed out that in order to maintain the salary of the existing position or selfishness of tunneling, the management sometimes concealed the negative information. Concentration of equity can improve the supervision ability of the board of directors, which is beneficial in order to expose the self-profit behavior of managers.

From the perspective of behavioral motivation theory, managers may have opportunistic behaviors in the process of company operation and resource allocation. Chin et al. (2009) found when there was an excessive concentration of equity in company. Because of investment oneness and higher risk of business innovation activities, major shareholders would like to present a certain tendency of risk aversion to prevent their expectations of short-term interests from being damaged, thus inhibited company's innovation activities. Bennedsen and Wolfenzon (2000) found the existence of major shareholders can effectively control other shareholders as well as increase managers' self-interest costs. In addition, Hao et al. (2016) pointed out that when several major shareholders exist in the ownership structure at the same time, if managers can't get a clearer understanding of "making proper relationship with major shareholders", then equity imbalances may occur, so stakeholders need to pay attention to the second-largest shareholder's governance.

\subsubsection{Research of Diversification Strategy Adjustment}

The enterprise uses strategic adjustment to deal with the dynamics of external environment and the challenge of uncertainty, which has received wide attention in academic circles. Some scholars understand enterprise strategic adjustment from organization's external environment (Burgelman, 1991) and organization's internal resources ability (Cui et al., 2001), while others discussed how do 
managers' and directors' features affect enterprises' strategic adjustment from the perspective of policy makers (Boeker, 1997). It is easy for scholars to assume that profit maximization is the ultimate goal of company decision-making, but they pay less attention to the choice of reference point and ignore the high risk of strategic adjustment. In fact, policy-makers' perceptions of strategic adjustment risk and their authority of making decisions and controlling risks are restricting their strategic adjustment motivation. The choice of diversification's reference point is worth discussing. In view of diversification's motivation and opportunity, the academic circle has obtained abundance production. Jia and Zhang (2005) compared the relevant research results of diversification motivation and opportunity in the eastern and western countries, pointing out that China's academic circles emphasized diversity's strong correlation with company's strength, and paid more attention to portfolio, government policy and institutional factors. Some scholars believe that, instead of increasing the value of the enterprise, diversification restricts the liquidity of the assets, raises managers' pressure and reduces their efficiency (Fu, 2001).

\subsection{Role Of The Executive Chain Network: Literature review}

Research results of domestic executives' social network are focused on two aspects: interlocking directors and executive political contact. In the light of interlocking directors, a great number of positive results mainly focus on the causes of the interlocking directors and empirical researches on company performance. Many companies in the network center have direct contact with other nodes in the network. It's easy for these companies to obtain heterogeneous information, shared knowledge, competitive opportunities and strategic advantages (Koka and Prescott, 2008). Through the network of chain directors, enterprises can obtain many information of other enterprises outside the organization. To a greater extent, enterprises can avoid resource constraints. The executive network consists of interlocking directors that are formed because directors hold their posts in different companies, and because executives serve on multiple boards at the same time. Hambrick et al. (1984) proposed upper echelons theory, which initiated the research of relationship between top management team(TMT)population characteristics and organizational output. Since then, some scholars have studied TMT's influence on strategic choice (Michel and Hambrick, 1992) and strategic change (Grimm and Smith, 1991). Chen and Wang (2016) believed embedding effect and locking effect made the TMT social network structure dual, and there was an inverted U relationship between TMT social network structure and collaborative innovation. Qiu et al. (2016) pointed out that political relationship and excessive investment of private enterprises appear to be positively correlated: political relations connecting will exacerbate excessive investment of the enterprise, while pyramidal control structure can weaken the influence.

\subsection{The Proposed Research Hypotheses}

It has become a universal appeal to promote more multi-dimensional and deep-level research, and understand the influencing mechanism of diversity more comprehensively. It is reasonable to pay attention to the regulation variables, but more efforts should be made to integrate, rather than agonize over adding moderator variable. Harrison and Klein (2007) divided "diversity" into "separation", "variety" and "disparity". "Separation" originates from the conflict of opinions. "Variety" emphasizes that members of the unit can be distinguished by functional background and external information source. The study of "disparity" focuses on factors such as power and status. This study applies the classification of diversity to board diversity, and divides it into board of directors' separation, variety and disparity. By controlling directors' separation and variety, the paper discusses how directors' disparity acts on the internal relations between shareholders and managers, and how it influences the strategic adjustment of enterprises.

\subsubsection{Board of Directors’ Disparity and Strategy Adjustment}

If the level of directors' disparity is extremely high, it means that the largest shareholders gain absolute control. Major shareholders weigh the risks and benefits and make resource allocation decisions. Wang et al. (2014) found in the case that major shareholders hold absolutely over the board of directors, major shareholders invested too much and their investment risk has not been 
effectively dispersed, so they will take some action to avoid "putting eggs in one basket". At the same time concentration causes the lack of supervision over major shareholders. When the largest shareholder holds far more than other directors, disparity is so high that the largest shareholder may be likely to "control and withhold information" to infringe on the rights and interests of other shareholders so as to reduce their own risk(Eisenhardt and Bourgeois, 1988). In addition to diversification of investment risk, acquisition of corporate earnings in various ways to make up for the performance of supervision responsibilities is also a possible reason for strategic adjustment. Li et al. (2009) pointed out that the concentration of equity would prompt the controlling shareholders to start a stronger intention to seek self-profit. At the same time, some managers are afraid of uncertainty accompanied by strategy adjustment. The major shareholders can carry supervisory role in a better way, which can prompt risk-averse managers to assume the uncertainty risk of diversification adjustment.

When board of directors' disparity is extremely low, there is little difference between the ten largest shareholders, and the resource allocation of enterprise will be tilted to agents' income. When board of directors' disparity is lower, the board's overall oversight ability will be weaker. Sanderson (2012) pointed out that if the supervision of the management layer is not perfect, managers may use the enterprise funds for personal enjoyment, or even falsify the cost to encroach on the enterprises' profit. It is also possible for these agents to increase power base by expanding company size. Due to the existence of multiple shareholders, the risks of implementing diversified strategic adjustment can be effectively dispersed, which can partially dispel the concerns of the board. Yang et al. (2015) found out a U-shape relationship between concentration degree of ownership and managers' innovation motivation by conducting a questionnaire survey. For risk-averse managers, the idea of strategic adjustment is no longer repressed and is good for business change when the board disparity is extremely low.

Equilibrium shareholding structure can effectively restrain the improper earnings tendency of shareholders and management. When equity concentration is appropriate, enterprises prefer strategic control to adjustment. In a strategic control mode, the enterprise's strategic plan reflects shareholders' purpose of grabbing interests, and achieving balance between managers' pursue of long-term enterprise development goal and their self-interest. There will be a balance in allocation of resources, enterprise will tend to appear as single business.

Based on above analysis, this study puts forward hypotheses1,

H1: The influence of board of directors' disparity on diversification strategic adjustment is positive U-shaped.

\subsubsection{Executive Chain Network's Moderating Effect}

When implementing diversification strategy, enterprises can achieve more collaboration by embedding social capital in social network. Information obtained through lateral coupling is advantageous for enterprises to produce higher-quality decisions. At the same time, current studies have found that executive chain network will moderate adjust the promoting effect of redundant resources to diversification strategy (Liu et al, 2011). Wu and He (2008) studied the influence of network on corporate diversification strategy from the perspective of executive political network, they found that executives' political networks can promote regional and business diversification.

When the company has only one big shareholder, if it's in a good network position, then the greatest shareholder is likely to diversify his or her investment risk, leading to a more diversified the company. In the same way, managers can get more resources and are more likely to be "over-diversified". With executive chain network's generalization, the target enterprise can contact with enterprises concentrating on other core businesses. According to path dependency theory, these companies are more likely to diversify from their core businesses.

Therefore, we can suggest hypotheses2,

H2: The positive U-type relationship between board of directors' disparity and diversification strategy adjustment can be mediated by executive chain network centrality degree. 


\section{Study Design}

\subsection{Samples and Data}

This study collected data and statistics of all A-share listed companies from 2010 to 2013, excluding financial classes and companies identified as ST. At the same time, the individual information disclosure of directors is not complete, and the listed companies with incomplete income statistics or incomplete financial data are excluded. In order to normalize the calculation result, balance panel is processed and 900 listed companies are finally obtained.

In this paper, data mainly comes from CSMAR and CCER, operating income data measuring diversification strategy adjustment is from CCER, other data is from CSMAR. This paper used UCINET, EXCEL and STATA to process the data.

\subsection{Variables}

\subsubsection{Independent Variable}

In the past, scholars haven't analysed in depth at "diversity”, until Harrison and Klein (2007) reexamined previous studies and renewed its concept, they put forward three kinds of segment patterns with different distribution forms, effects and theoretical mechanism. Higher disparity means more unequal membership and resources. This paper corresponded it to diversity of power hierarchy in the board, and choose it to be independent variable.

\subsubsection{Dependent Variable}

In this paper, Entropy is used to measure the diversification strategy adjustment. Entropy's larger, the strategic adjustment will be more diversified. $\mathrm{E}(\mathrm{s})=\sum_{i=1}^{n} S_{\mathrm{i}} \ln (1 / \mathrm{si})$, Si means the ratio of income in industry to total income. When the income of enterprise comes from the same industry, $\mathrm{Si}$ is 1 and the Entropy value is 0 . Items such as adjustment, balance, or internal offset are amortized into each business, and categorized divisions those are not explicit into other businesses.

\subsubsection{Moderator Variable}

According to executives' information of listed companies, This paper signs their names (exclude duplication of name) and corresponding companies, one-mode matrix $C_{\alpha, \beta}\left[\begin{array}{l}1 \\ 0\end{array}\right.$ is which constructs the coupling relationship between executives, if two executives are working in two boards of directors or more at the same time, their relationship is 1.We imported this matrix into UCINET to calculate centrality degree index. This study chose betweenness (representing the number of chain directors) and eigenvector centrality (representing the quality of chain directors). Financial enterprises and ST enterprises are not excluded in order to guarantee the boundary integrity of this network.

\subsubsection{Control Variables}

Board of directors' variety refers to the diversity of information in board members due to education background, training and experience. The greater this value is, more open the board members are to different attitudes. Board of directors' separation is mainly according to board of directors' internality/externalities and relationship/non- relationship to distinguish, contains consideration of independent board of directors' proportion and members hold concurrent internal and external positions. If the enterprise is larger, resources and information it has will be more, and larger companies usually have more resources to support diversified businesses than small companies. The natural logarithm of enterprises' total assets is used as the measurement index of enterprise scale. In addition, this article divided listed companies into four types (from 1 to 4 represents central enterprise, provincial state-owned enterprises, city state-owned enterprises, private enterprises (including foreign investment, collective and privately-owned) according to their ownership. In order to ensure the empirical results are accurate and reliable, other control variables in this paper are asset-liability ratio, independent director proportion and enterprise performance. 


\section{Empirical Analysis}

There are two empirical parts in this paper. Firstly, it is verified that board of directors' disparity has influence on the diversification strategy of enterprises. Secondly, the regulation effect of the chain network is discussed and the related hypotheses are verified. Table 1 shows the results of testing.

Hanns et al. (2016) argue that researchers should determine $U$ from the quadratic term coefficient, curve turning point and left/right side slope, from table 1 we can know if don't join control variables, the quadratic term coefficient is 0.067 and the significant is at $1 \%$ level, the turning point is 0.687 , bigger than 0.322 , smaller than 3.133 , between the minimum and maximum. Take board of directors' disparity's minimum level $\mathrm{X}_{\mathrm{l}}$, get the left side of the slope 0.152 , Take board of directors' disparity's maximum level $\mathrm{X}_{\mathrm{h}}$, calculate on the right side of the slope 0.225 , then fit the conditions, this figure is right in the u-shaped curve. After control variables were added, the quadratic coefficient was 0.0653 , and the significant is at $1 \%$ level, the turning point is 0.0637 , in the value range of independent variables. Take board of directors' disparity's minimum level $\mathrm{X}_{1}$, get the left side of the slope 0.163 , Take board of directors' disparity's maximum level $\mathrm{X}_{\mathrm{h}}$, calculate on the right side of the slope 0.204 , so this figure is right in the u-shaped curve. Therefore, Hypothesis 1 is proved, The influence of board of directors' disparity on diversification strategic adjustment is positive. When the right is more dispersed or more concentrated, there will be more enterprise management business units, and strategic adjustment will towards diversification.

Table1 The result of main effect's testing and Moderating effect's testing.

\begin{tabular}{|c|c|c|c|c|c|c|}
\hline VARIABLES & (1) & (2) & (3) & (4) & (5) & (6) \\
\hline disparity & $\begin{array}{c}-0.195 * * \\
(0.0795)\end{array}$ & $\begin{array}{c}-0.205^{* * *} \\
(0.0788)\end{array}$ & $\begin{array}{c}-0.205^{* * *} \\
(0.0788)\end{array}$ & $\begin{array}{c}-0.191 * * \\
(0.0788)\end{array}$ & $\begin{array}{c}-0.187 * * \\
(0.0785)\end{array}$ & $\begin{array}{c}-0.189 * * \\
(0.0786)\end{array}$ \\
\hline disparity $^{2}$ & $\begin{array}{c}0.0670 * * * \\
(0.0194)\end{array}$ & $\begin{array}{c}0.0653^{* * *} \\
(0.0192)\end{array}$ & $\begin{array}{c}0.0656^{* * *} \\
(0.0192)\end{array}$ & $\begin{array}{c}0.0621^{* * *} \\
(0.0192)\end{array}$ & $\begin{array}{c}0.0615^{* * *} \\
(0.0191)\end{array}$ & $\begin{array}{c}0.0622^{* * * *} \\
(0.0192)\end{array}$ \\
\hline Betweenness & & & $\begin{array}{l}1.822 \\
(4.335)\end{array}$ & $\begin{array}{l}2.973 \\
(4.341)\end{array}$ & $\begin{array}{c}2.704 \\
(4.319)\end{array}$ & $\begin{array}{c}2.084 \\
(4.342)\end{array}$ \\
\hline Eigenvector & & & $\begin{array}{l}0.000618 \\
(0.00157)\end{array}$ & $\begin{array}{l}0.000526 \\
(0.00157)\end{array}$ & $\begin{array}{l}0.000593 \\
(0.00156)\end{array}$ & $\begin{array}{l}0.000696 \\
(0.00157)\end{array}$ \\
\hline $\begin{array}{l}\text { Betweenness* } \\
\text { disparity }\end{array}$ & & & & 16.03 & & 14.14 \\
\hline $\begin{array}{l}\text { Betweenness* } \\
\text { disparity }^{2}\end{array}$ & & & & $\begin{array}{l}(29.39) \\
-8.043\end{array}$ & & $\begin{array}{c}(49.86) \\
-0.594\end{array}$ \\
\hline $\begin{array}{l}\text { Eigenvector* } \\
\text { disparity }\end{array}$ & & & & (7.270) & 0.00652 & $\begin{array}{l}(12.13) \\
0.00162\end{array}$ \\
\hline $\begin{array}{l}\text { Eigenvector* } \\
\text { disparity }^{2}\end{array}$ & & & & & $\begin{array}{l}(0.0101) \\
-0.00391\end{array}$ & $\begin{array}{l}(0.0173) \\
-0.00350\end{array}$ \\
\hline $\mathrm{CV}$ & uncontrolled & controlled & controlled & controlled & $\begin{array}{l}(0.00249) \\
\text { controlled }\end{array}$ & $\begin{array}{l}(0.00418) \\
\text { controlled }\end{array}$ \\
\hline $\mathrm{N}$ & 3,600 & 3,600 & 3,600 & 3,600 & 3,600 & 3,600 \\
\hline $\mathrm{F}$ & $23.92 * * *$ & $17.37 * * *$ & $14.33 * * *$ & $13.19 * * *$ & $14.9 * * *$ & $13.07 * * *$ \\
\hline $\begin{array}{l}\text { R-squared } \\
\text { Adi R }{ }^{2}\end{array}$ & $\begin{array}{c}0.013 \\
0.0126\end{array}$ & $\begin{array}{c}0.042 \\
0.0393\end{array}$ & $\begin{array}{c}0.042 \\
0.0391\end{array}$ & $\begin{array}{c}0.046 \\
0.0422\end{array}$ & $\begin{array}{c}0.051 \\
0.0478\end{array}$ & $\begin{array}{c}0.052 \\
0.0479\end{array}$ \\
\hline
\end{tabular}

*** $\mathrm{p}<0.01, * * \mathrm{p}<0.05, * \mathrm{p}<0.1$

Model 4 shows positive liner correlation effect between board of directors' disparity and executive chain network's betweenness were not significant, neither do the quadratic negative correlation effect. Although judging from quadratic term coefficient, after adding interaction terms, the U-shaped relationship becomes more smooth, but the regulation has not been proved effectively. Model 5 shows positive liner correlation effect between board of directors' disparity and executive 
chain network's eigenvector were not significant, neither do the quadratic negative correlation effect. After adding interaction terms, the U-shaped relationship becomes more smooth, but the regulation is also not significant. The data validation results are not consistent with hypothesis 2 , so hypothesis 2 is rejected.

\section{Conclusions and Research Prospects}

Based on the combing of the literature on the board diversification, this paper finds that the classification of the board does not form a clear pattern, mostly on the surface diversity, and the most results of the same result variables do not form a unified conclusion. Taking the diversity of power hierarchy as the entry point, at different levels of diversity of power hierarchy, firms generate different principal-agent problems; At different levels of the diversity of power hierarchy, diversification strategy adjustment depends on the will of different subjects, and thus the impact of firms diversification strategy decision mechanism is also different. This paper studies the diversification strategy of the enterprise from the board of directors and managers, also probes into the adjustment effect of board network, and examines the applicability and explanatory power of resource dependence theory in this relationship, the results show that:

(1) The diversity of board power hierarchy, and diversification of strategic adjustment presents a positive U-type relationship. When the level of the board of directors of diversity of power hierarchy is low, the internal equity is more dispersed, Which to some extent weakens the board's supervision and control capabilities, the board may not be able to catch and stop the manager from using diversification for personal gain, Or when the board control atmosphere is not so strong, the manager's career pursuit, business management initiative will not be too curbed. In this case, the firm will generate diversification strategy adjustment due to the will of the management layer. When the level of the board of directors of diversity of power hierarchy is high, the internal equity is relatively concentrated, managers, major shareholders are subject to supervision constraints. On the one hand this can effectively avoid the major shareholders' or managers' blind diversification to affect business operations, but on the other hand, with the gradual improvement of the level of the diversity of board power hierarchy, communication costs increase, internal conflicts arise or intensified, that is the formation of split small groups, the enthusiasm of both sides of change is more or less affected, it is possible to miss the right time to diversify. While the level of the diversity of board power hierarchy is high, the largest shareholder holding high, he has overwhelming voice advantage in the board of directors decision-making because of absolute holding position, on the one hand, large shareholders have higher decision-making efficiency, which can help firms to improve the level of utilization of resources, but at the same time, large shareholders may also be inappropriate diversification for the purpose of decentralizing risk or making up for regulatory costs.

(2) The centrality index of the board network is not significant for the adjustment of the relationship between the diversity of board power hierarchy and the diversification strategy adjustment. Based on the original hypothesis, the larger intermediate center index means that the wider the scope of the chain directors included in the network, the more extensive the way of firms to obtain resources, the more areas firms can get involved, and the more conducive to diversification operating. The eigenvector centrality makes the positive U-shaped curve flat, that is, at the same level of board-level diversity, the larger the number of chain directors, the lower the degree of corporate diversification, but this effect is not significant. From the point of view of resource-based view, the higher the network characteristic vector of chain executives, the higher the quality of resources such as information in communication process, and the same firms should be more likely to diversify the strategy. But the result is the opposite of the original hypothesis. Possible reasons are: the misunderstanding of the mechanism of the chain of executives. Only considering the level of access to the location of the firms, but not on the chain brought about by the more sensitive risk perception analysis, while the chain also makes the relationship between the board and the manager more complex and changeable, in a follow-up study, we should have a more comprehensive and in-depth understanding of the role of the chain of executives. 
(3) In general, this paper analyzes the motivations of the diversification strategy of the firms, reveals the relationship between the diversity of the board and the diversification decision, and points out that the change of the ownership structure will affect the business adjustment of firms. There are three possibilities for business diversification, including discount, premium and neutral. We cannot suppress the pluralistic demands and adhere to the single business unit, but blindly doing business diversification is harmful. According to the research results of this paper, firms can adjust to the long-term development needs through the ownership structure adjustment, under different ownership structure to guard against the self-interest strategy adjustment behavior of different subjects, and make diversified beneficiaries for enterprises to achieve green governance upgrade. At the same time, although the role of the chain of executives does not produce along the expected path, but also we recognize the complexity of this mechanism, companies should be more carefully established chain network.

(4)The research of this paper is superficial. Firstly, board diversification is classified into governance structure, knowledge and experience, and the diversity of power hierarchy. Although this classification method is an innovation, its rationality deserves further consideration. Secondly, in the interpretation of the diversity of power hierarchy, this paper did not take the manager of the actual degree of freedom of control into account. Finally, because the point of thinking is the board of directors and the manager "who has the final say", then taking the implementation of the manager in violation of the wishes of the board and the company's long-term strategy into account, we can redefine the strategic shift as the explanatory variable, a more comprehensive understanding of the two sides of the competition.

\section{References}

[1] Zhu D H, Shen W. Why do some outside successions fare better than others? The role of outside CEO's prior experience with board diversity [J]. Strategic Management Journal, 2015, 37(13), 2695-2708.

[2] Sutcliffe K M. What executives notice: Accurate perceptions in top management teams [J]. Academy of Management Journal, 1994, 37(5), 1360-1378.

[3] Kim J., Li Y., Zhang L. Corporate Tax Avoidance and Stock Price Crash Risk: Firm-Level Analysis, Journal of Financial Economics, 2011a (100), 639-662.

[4] Bennedsen, Morten; Wolfenzon, Daniel. The balance of power in closely held corporations [J]. Journal of Financial Economics, 2000, 58(1-2), 113-139.

[5] Hambrick D C, Mason P A.Upper echelons: the organization as a reflection of its top managers [J]. Academy of Management Review, 1984, 9(2), 193-206.

[6] Michel J G, Hambrick D C.Diversification posture and the characteristics of the top management team [J]. Academy of Management Journal, 1992, 35(1), 9-37

[7] Grimm C, Smith K G. Management and organizational change: a note on the railroad industry [J]. Strategic Management Journal, 1991, 12(7), 557-562

[8] Sanderson J.Risk, Uncertainty and Governance in Megaprojects: A Critical Discussion of Alternative Explanations [J]. International Journal of Project Management, 2012, 30(4), 432-443.

[9] Wu Jingfei, He Dajun, Lin Riwei, et al. Top managers' political networks and corporate's diversification strategies: Social Capital Perspective- Empirical analysis based on panel data of Listed Companies in China [J]. Management World, 2008(8), 107-118. 